\title{
PERANGKAT LUNAK BANTU PALEONTOLOGI PENENTUAN USIA FOSIL PURBA MENGGUNAKAN PENDEKATAN RULE BASED ARCHITECTURE
}

\author{
Faulinda Ely Nastiti ${ }^{1}$, Pipin Widyaningsih ${ }^{2}$
}

\author{
${ }^{1,2}$ STMIK Duta Bangsa \\ Email: ${ }^{1}$ faulinda.en@gmail.com ${ }^{2}$ pipinwidyaningsih@gmail.com
}

(Naskah masuk: 8 Agustus 2016, diterima untuk diterbitkan: 8 September 2016)

\begin{abstract}
Abstrak
Situs Sangiran merupakan situs purba digunakan untuk musium dan konservasi fosil-fosil yang ditemukan pada kawasan Sangiran. Kegiatan konservasi dilakukan oleh seksi Eksplorasi dengan melakukan analisis laboratorium menggunakan metode relatif. Metode relatif dapat memungkinkan perbedaan hasil usia fosil. Perangkat lunak bantu dibuat dengan tujuan untuk mengurangi subjektifitas dan ketidaksamaan persepsi penentuan usia fosil. Perangkat lunak dibangun berdasarkan kriteria lapisan tanah yang dimiliki oleh fosil tersebut dengan kaidah-kaidah yang di gunakan oleh seksi Eksplorasi Balai Besar Situs Manusia Purba Sangiran. Penelitian ini mengadopsi metode penelitian Software Engineering Expert System. Basis aturan yang digunakan adalah metode Forward Chaining, dimana penentuan usia fosil didapatkan dari penginputan ciri-ciri lapisan tanah dimana fosil ditemukan. Perangkat Lunak Paleontology memiliki 13 basis aturan. Basis aturan penelusuran usia fosil yang dikembangkan sesuai dengan akuisisi pengetahuan seksi Eksplorasi. Perangkat lunak membantu para ahli geologi untuk menentukan usia fosil secara objektif sesuai kaidah-kaidah penentuan umur fosil dengan metode Relatif. Pengujian tingkat kepercayaan Perangkat Lunak diukur dengan metode Certainly Factor.
\end{abstract}

Kata kunci: Sistem Pakar,Penelusuran Kedepan, Paleontology, Sangiran, Tingkat Kepercayaan

\begin{abstract}
Sangiran is an archeology site that is used as museum and fossil conservation that is found around Sangiran. Conservation activities carried out by Exploration Devision by conducting laboratory analysis using relative method. Those result some contradiction between on the statement of the fossil age.

Then a software is built to help reduce subjectivity and perception of inequalities determining the age of fossils. The software is built based on the criteria of layers of land owned by the fossils as ruled by Sangiran Exploration Devision. This study adopts the research Software Engineering Expert System. Forward Chaining method is the basis of rules that are used, where the determination of the age of the fossils obtained from inputting the characteristics of the soil layer discovery of fossils.Paleontology software has 13 base rules to investigate the fossil age based on knowledge acquisition by Sangiran Exploration Devision. The software helps the geologists to determine the age of fossils objectively as written on the fossils age determination. Software testing conducted to measure confidence level by using Certanly FactorMetode.
\end{abstract}

Keywords: Expert System, Forward Chaining, Paleontologi, Sangiran, Certainly Factor

\section{PENDAHULUAN}

Situs Sangiran, merupakan balai konservasi Paleontologi dan merupakan musium terbesar di Asia (Wahyu, 2012). Situs Sangiran diperkirakan masih memiliki beragam fosil purba yang terkubur di dalam lapisan tanah seluas kurang lebih $78 \mathrm{~km} 2$ (Rendra, 2013).

Kegiatan penentuan usia fosil di Situs Manusia Purba Sangiran dilakukan oleh seksi Eksplorasi dengan melakukan analisis laboratorium menggunakan metode Relatif (Nugraha, 2013). Metode Relatif merupakan penentuan usia fosil yang mengacu pada lapisan tanah dimana fosil ditemukan (Noor, 2012).

Masalah utama pada penentuan usia fosil adalah adanya perbedaan pendapat para ahli geologi pada penilaian unsur tanah. Hal ini berdampak pada penentuan usia fosil dengan hasil yang tidak sama pada tiap ahli geologi.

Nilai subjektifitas perhitungan usia fosil pada situs sangiran tersebut dapat ditanggulangi dengan memanfaatkan perangkat lunak bantu/aplikasi menggunakan pendekatan Rule Based Arhitecture. Rule Based Architecture dalam sistem pakar merupakan pendekatan dengan pernyataan bersyarat yang berisi kondisi, tindakan, dan hasil berdasarkan fakta-fakta dan gejala-gejala(Abraham, 2005).

Dalam kasus Knowledge-system, komponen rule based merupakan hal terpenting sebagai dasar dari penciptaan dan inferensi aturan-aturan (Ligeza, 2006). Inferensi aturan-aturan Perangkat lunak bantu ini akan membantu ahli geologi dalam menentukan usia fosil lebih objektif. 


\section{METODOLOGI}

1. Research \& Review, peneliti melakukan observasi pada Situs sangiran untuk melihat proses dan prosedur penentuan umur fosil yang dilakukan oleh ahli geologi Seksi Eksplorasi.

2. Identifikasi Masalah, melakukan identifikasi masalah terhadap objek yang diteliti. Pada tahap ini penelitian dilakukan dengan cara wawancara kepada Ahli geologi seksi Eksplorasi Situs Sangiran untuk mengetahui alasan keterlambatan penentuan usia fosil.

3. Analisis kebutuhan, pada tahap ini kebutuhan dan keinginan pengguna terhadap prototype aplikasi yang dikembangkan didapatkan dari wawancara. Analisis Kebutuhan akan menggali kubutuhan fungsional dan human interaction perangkat lunak dan penggunanya.

4. Akuisisi pengetahuan, dilakukan dengan cara menggali pengetahuan dan aturan-aturan dalam memutuskan/menentukan usia fosil dengan metode relatif. Pada tahap ini peneliti akan menggambarkan pohon keputusan berdasarkan aturan-aturan yang di berikan oleh ahli geologi seksi eksplorasi situs Sangiran.

5. Tahap perancangan dan pembuatan program

a. Tahap Perancangan melakukan aktifitas untuk merancang cetak biru perangkat lunak yang akan dikembangkan berdasarkan spesifikasi kebutuhan fungsional.

b. Pembuatan program difokuskan untuk merealisasikan cetak biru menjadi perangkat lunak. Perangkat lunak akan memberikan 2 jenis layanan: (1) Layanan untuk bisa mengupdate pengetahuan dilakukan oleh pakar dalam hal ini adalah seorang ahli geologi seksi Eksploitasi, (2) Layanan untuk melakukan penelusuran terhadap usia fosil dengan metode relatif berdasarkan lapisan tanah yang dimiliki oleh situs Sangiran.

6. Pengujian perangkat lunak, dilakukan untuk melihat kesesuaian perangkat lunak dengan spesifikasi kebutuhan fungsional dan non fungsional. Hasil dari tahap ini adalah jawaban apakah perangkat lunak layak digunakan dengan sempurna atau memerlukan perbaikan atau penambahan fitur

7. Distribusi, pada tahap ini prototype yang sudah dinyatakan layak oleh tim penguji akan di distribusikan ke situs Sangiran seksi Eksplorasi agar dapat digunakan sebagaimana tujuan dan manfaat yang ingin dicapai oleh peneliti.

\section{HASIL DAN PEMBAHASAN}

\subsection{Indetifikasi Masalah}

Sistem penentuan umur fosil dengan metode relatif meliputi pengamatan langsung ke lokasi penemuan fosil oleh ahli geologi untuk melakukan penelitian lapisan tanah. Hasil penelitian ahli geologi dicatat dan dianalisis dalam laboratorium untuk menentukan usia. Setelah diperoleh hasil usia fosil lalu diregistrasi dan dibuat laporan mengenai penemuan fosil dengan menggunakan Ms. Word atau Ms. Excel. Fathoni (Fathoni, 2016) mengemukakan bahwa hasil penentuan usia fosil memiliki unsur subjektifitas yang mengakibatkan perbedaan hasil umur fosil berbeda-beda oleh tiap ahli geologi. Hal ini dikarenakan tiap ahli geologi memiliki pendapat sendiri-sendiri mengenai jenis tanah yang dimiliki oleh fosil.

\subsection{Analisa Kebutuhan}

Tahap ini mendefisnisikan layanan dan apa saja yang di dapatkan oleh pengguna aplikasi. Dibagi menjadi 2 user yaitu Pakar (Ahli geologi) dan Pengguna (Peneliti) :

1. Pakar (Ahli Geologi)

a) Pakar dapat login ke menu utama.

b) Sistem dapat memberikan peringatan saat login jika password yang dimasukan salah.

c) Pakar dapat melakukan pengolahan data jenis tanah meliputi tambah, hapus, dan simpan data jenis tanah.

d) Pakar dapat melakukan pengolahan data formasi tanah meliputi tambah, hapus, dan simpan data formasi tanah.

e) Pakar dapat melakukan pengolahan data lapisan tanah meliputi tambah, hapus, dan simpan data lapisan tanah.

f) Pakar dapat menambahkan aturan relasi data jenis, formasi dan lapisan tanah.

g) Pakar dapat melakukan proses penelitian usia fosil.

h) Sistem dapat merekam data jawaban dari pertanyaan dalam proses penelitian usia fosil.

i) Sistem dapat memberikan hasil penelitian usia fosil.

j) Pakar dapat melakukan registrasi dan menyimpan hasil usia fosil.

k) Sistem dapat melakukan simpan data gambar fosil.

1) Pakar dapat melakukan pengolahan laporan data usia fosil.

2. Pengguna (Peneliti)

a) Pengguna dapat melakukan proses penelitian usia fosil.

b) Sistem dapat merekam data jawaban dari pertanyaan dalam proses penelitian usia fosil.

c) Sistem dapat memberikan hasil penelitian usia fosil.

d) Pengguna dapat melakukan registrasi dan menyimpan hasil usia fosil.

e) Sistem dapat melakukan simpan data gambar fosil.

f) Pengguna dapat melakukan pengolahan laporan data usia fosil.

\subsection{Akuisisi Pengetahuan}


Sumber-sumber yang dijadikan sumber pengetahuan antara lain adalah :

1. Bpk Muhammad Rais Fathoni, ST menjabat sebagai seksi Eksplorasi (ahli Geologi) Balai Situs Manusia Purba Sangiran yang ditunjuk sebaga Pakar dalam penelitian ini.

2. Jurnal penelitian dengan judul; " Peningkatan Kreativitas Desan Cindramata untuk mendukung Museum Sangiran Kabupaten Sragen Jawa Tengah"

3. Geological Research and Developmen Center Directorate General of Geology and Mineral Resources Ministry of Mines and Energi, Bandung, Indones

Dengan hasil akusisi pengetahuan sebagai berikut: Tabel 1 Akusisi Pengetahuan

\begin{tabular}{|c|c|c|c|c|c|c|}
\hline $\begin{array}{l}\mathbf{N} \\
\mathbf{0}\end{array}$ & $\begin{array}{l}\text { Jenis } \\
\text { Tan } \\
\text { ah }\end{array}$ & $\begin{array}{l}\text { Ciri - } \\
\text { ciri }\end{array}$ & $\begin{array}{l}\text { Form } \\
\text { asi } \\
\text { Tana } \\
\text { h } \\
\end{array}$ & $\begin{array}{l}\text { Lapis } \\
\text { an } \\
\text { Tana } \\
\text { h } \\
\end{array}$ & $\begin{array}{l}\text { Kete } \\
\text { balan } \\
\text { Tana } \\
\text { h } \\
\end{array}$ & $\begin{array}{l}\text { Umu } \\
\mathbf{r}\end{array}$ \\
\hline \multirow[t]{6}{*}{1} & \multirow[t]{6}{*}{$\begin{array}{l}\text { Lem } \\
\text { pung }\end{array}$} & \multirow{4}{*}{$\begin{array}{l}\text { Lemp } \\
\text { ung } \\
\text { warna } \\
\text { biru, } \\
\text { endap } \\
\text { an air } \\
\text { laut }\end{array}$} & \multirow[t]{4}{*}{$\begin{array}{l}\text { Form } \\
\text { asi } \\
\text { Kalib } \\
\text { eng }\end{array}$} & $\begin{array}{l}\text { Kalib } \\
\text { eng } \\
\text { Terba } \\
\text { wah }\end{array}$ & $\begin{array}{l}\text { Menc } \\
\text { apai } \\
107 \mathrm{~m}\end{array}$ & $\begin{array}{l}3.000 \\
.000 \\
\text { Tahu } \\
\mathrm{n}\end{array}$ \\
\hline & & & & $\begin{array}{l}\text { Kalib } \\
\text { eng } \\
\text { kedua }\end{array}$ & $\begin{array}{l}\text { Menc } \\
\text { apai } 4 \\
-7 \mathrm{~m}\end{array}$ & $\begin{array}{l}2.600 \\
.000 \\
\text { Tahu } \\
\mathrm{n}\end{array}$ \\
\hline & & & & $\begin{array}{l}\text { Kalib } \\
\text { eng } \\
\text { ketig } \\
\text { a }\end{array}$ & $\begin{array}{l}\text { Menc } \\
\text { apai } 1 \\
-2,5 \\
\mathrm{~m}\end{array}$ & $\begin{array}{l}2.200 \\
.000 \\
\text { Tahu } \\
\mathrm{n}\end{array}$ \\
\hline & & & & $\begin{array}{l}\text { Kalib } \\
\text { eng } \\
\text { keem } \\
\text { pat }\end{array}$ & $\begin{array}{l}\text { Menc } \\
\text { apai } 1 \\
\text { Meter }\end{array}$ & $\begin{array}{l}1.800 \\
.000 \\
\text { Tahu } \\
\mathrm{n}\end{array}$ \\
\hline & & \multirow{2}{*}{$\begin{array}{l}\text { Lemp } \\
\text { ung } \\
\text { warna } \\
\text { hitam, } \\
\text { endap } \\
\text { an } \\
\text { lahar } \\
\text { dingi } \\
\text { n } \\
\text { (breks } \\
\text { i } \\
\text { vulka } \\
\text { nik) }\end{array}$} & \multirow[t]{2}{*}{$\begin{array}{l}\text { Form } \\
\text { asi } \\
\text { Pucan } \\
\text { gan }\end{array}$} & $\begin{array}{l}\text { Puca } \\
\text { ngan } \\
\text { bawa } \\
\text { h }\end{array}$ & $\begin{array}{l}\text { Menc } \\
\text { apai } \\
0,7- \\
50 \mathrm{~m}\end{array}$ & $\begin{array}{l}1.700 \\
.000 \\
\text { Tahu } \\
\mathrm{n}\end{array}$ \\
\hline & & & & $\begin{array}{l}\text { Puca } \\
\text { ngan } \\
\text { atas }\end{array}$ & $\begin{array}{l}\text { Menc } \\
\text { apai } \\
100 \mathrm{~m}\end{array}$ & $\begin{array}{l}800.0 \\
00 \\
\text { Tahu } \\
\mathrm{n}\end{array}$ \\
\hline 2 & $\begin{array}{l}\text { Gam } \\
\text { ping }\end{array}$ & $\begin{array}{l}\text { Batu } \\
\text { gampi } \\
\text { ng } \\
\text { dan } \\
\text { batu } \\
\text { pasir }\end{array}$ & $\begin{array}{l}\text { Form } \\
\text { asi } \\
\text { Grenz } \\
\text { bank }\end{array}$ & $\begin{array}{l}\text { Lapis } \\
\text { an } \\
\text { grenz } \\
\text { bank }\end{array}$ & $\begin{array}{l}\text { Menc } \\
\text { apai } \\
0,1- \\
46,3 \\
\text { m }\end{array}$ & $\begin{array}{l}730.0 \\
00 \\
\text { Tahu } \\
\mathrm{n}\end{array}$ \\
\hline 3 & Pasir & $\begin{array}{l}\text { Pasir } \\
\text { silang } \\
\text { siur } \\
\text { atau }\end{array}$ & $\begin{array}{l}\text { Form } \\
\text { asi } \\
\text { Kabu } \\
\text { h }\end{array}$ & $\begin{array}{l}\text { Kabu } \\
\text { h } \\
\text { bawa } \\
\text { h }\end{array}$ & $\begin{array}{l}\text { Menc } \\
\text { apai } 6 \\
-20 \\
\mathrm{~m}\end{array}$ & $\begin{array}{l}720.0 \\
00 \\
\text { Tahu } \\
\mathrm{n}\end{array}$ \\
\hline
\end{tabular}

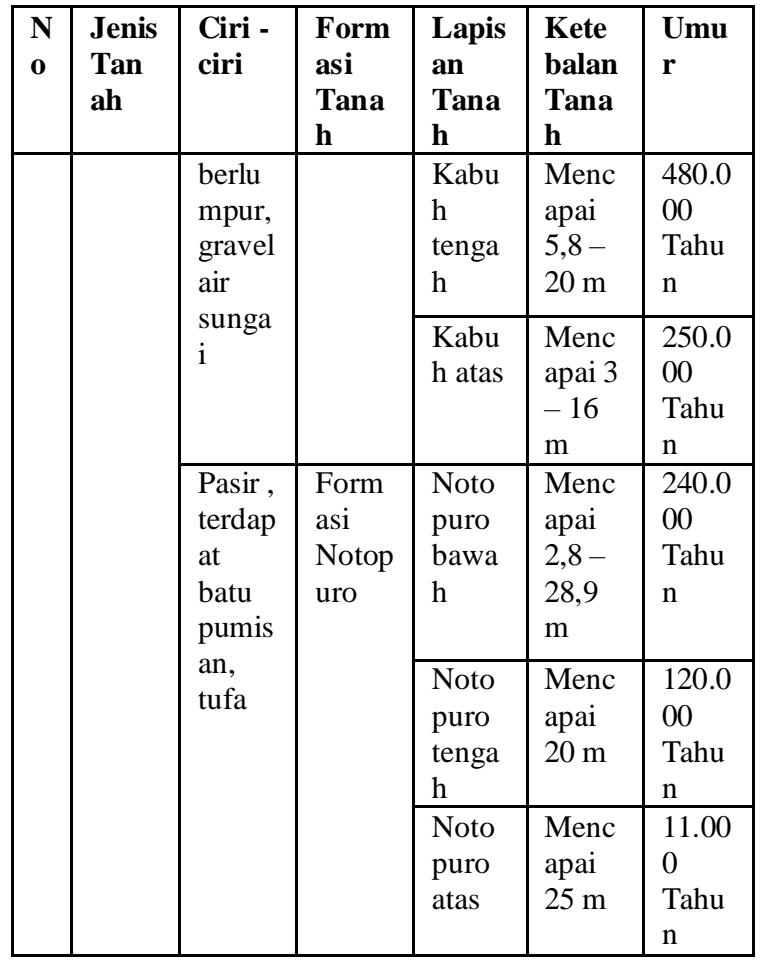

Berdasarkan tabel Tabel 1, akusisi pengetahuan diturunkan kedalam Representasi Pengetahuan (Subasi, 2007). Representasi digambarkan dengan pohon keputusan (Tree, n.d.) dari pembagian usia lapisan tanah. Pohon Keputusan dapat dilihat pada Gambar 1 berikut :

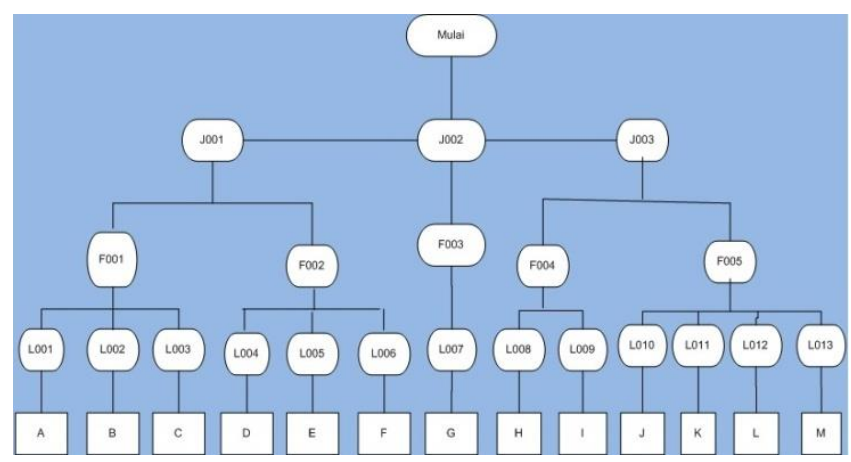

Gambar 1 Pohon Keputusan

Keterangan :

Kode J001 - J003 menunjukan jenis tanah

Kode F001 - F005 menunjukan formasi tanah

Kode L001 - L013 menunjukan lapisan tanah.

Kode A - M menunjukan usia fosil.

\subsection{Basis Aturan (Role Base)}

Basis Aturan merupakan representasi dari penalaran manusia terhadap suatu pemecahan masalah (Fairuz, 2005). Forward Chaining merupakan salah satu teknik dari Basis aturan(Barry, 2008). Forward Chaining menelusuri rantai faktafakta temuan yang mengasilkan kesimpulan (Bacchus 
\& Ady, 2001). Berikut Basis aturan Forward Chaining dalam menganalisis usia fosil :

1. RULE Usia Fosil 11.000 Tahun IF Tanah lokasi penemuan berpasir Is Yes AND Mengandung grave, abu vulkanik dan lanau Is Yes

AND Merupakan lapisan atas Is Yes AND Memiliki ketebalan 25 meter Is Yes AND Mengandung pasir besi Is No THEN Lapisan Notopuro atas usia 200.000 Tahun

2. RULE Usia Fosil 120.000 Tahun IF Tanah lokasi penemuan berpasir Is Yes AND Mengandung grave, abu vulkanik dan lanau Is Yes

AND Merupakan lapisan atas Is Yes AND Memiliki ketebalan 20 meter Is Yes AND Mengandung pasir besi Is No THEN Lapisan Notopuro tengah usia 220.000 Tahun

3. RULE Usia Fosil 240.000 Tahun IF Tanah lokasi penemuan berpasir Is Yes AND Mengandung grave, abu vulkanik dan lanau Is Yes

AND Merupakan lapisan atas Is Yes AND Memiliki ketebalan 3,2-28,9 meter Is Yes AND Mengandung pasir besi Is No THEN Lapisan Notopuro bawah usia 240.000 Tahun

4. RULE Usia Fosil 250.000 Tahun

IF Tanah lokasi penemuan berpasir Is Yes AND Mengandung lumpur Is Yes AND Memiliki ketebalan 3-16 meter Is Yes AND Mengandung pasir besi Is Yes THEN Lapisan Kabuh atas usia 250.000 Tahun

5. RULE Usia Fosil 425.000 Tahun

IF Tanah lokasi penemuan berpasir Is Yes AND Mengandung lumpur Is Yes AND Memiliki ketebalan 5,8-20 meter Is Yes AND Mengandung pasir besi Is Yes THEN Lapisan Kabuh tengah usia 425.000 Tahun

6. RULE Usia Fosil 600.000 Tahun IF Tanah lokasi penemuan berpasir Is Yes AND Mengandung lumpur Is Yes AND Memiliki ketebalan 6-50 meter Is Yes AND Mengandung pasir besi Is Yes THEN Lapisan Kabuh bawah usia 600.000 Tahun

7. RULE Usia Fosil 700.000 Tahun IF Tanah lokasi penemuan berupa lempung Is Yes

AND berwarna hitam kehijauan Is Yes AND Memiliki ketebalan 0,1-46,3 meter Is Yes AND Merupakan lapisan pembatas Is Yes THEN Lapisan Grezbenk usia 700.000 Tahun

8. RULE Usia Fosil 800.000 Tahun IF Tanah lokasi penemuan berupa lempung Is Yes AND berwarna hitam kehijauan Is Yes
AND Memiliki ketebalan 100 meter Is Yes AND Merupakan endapan lahar dingin Is Yes AND Mengandung lanau Is No

THEN Lapisan Pucangan Atas usia 800.000

Tahun

9. RULE Usia Fosil 1.700.000 Tahun

IF Tanah lokasi penemuan berupa lempung Is Yes

AND berwarna hitam kehijauan Is Yes

AND Memiliki ketebalan 0,7-50 meter Is Yes AND Merupakan endapan lahar dingin Is Yes AND Mengandung lanau Is No THEN Lapisan Pucangan bawah usia 1.700.000 Tahun

10. RULE Usia Fosil 1.800.000 Tahun IF Tanah lokasi penemuan berupa lempung Is Yes

AND berwarna abu-abu kebiruan Is Yes AND Memiliki ketebalan 1 meter Is Yes AND Merupakan endapan laut dalam Is Yes AND Mengandung lanau Is Yes THEN Lapisan Kalibeng Atas usia 1.800.000 Tahun

11. RULE Usia Fosil 2.200.000 Tahun IF Tanah lokasi penemuan berupa lempung Is Yes

AND berwarna abu-abu kebiruan Is Yes AND Memiliki ketebalan 2,5 meter Is Yes AND Merupakan endapan laut dalam Is Yes AND Mengandung lanau Is Yes THEN Lapisan Kalibeng Tengah usia 2.200.000 Tahun

12. RULE Usia Fosil 2.600.000 Tahun IF Tanah lokasi penemuan berupa lempung Is Yes

AND berwarna abu-abu kebiruan Is Yes AND Memiliki ketebalan 4-7 meter Is Yes AND Merupakan endapan laut dalam Is Yes AND Mengandung lanau Is Yes THEN Lapisan Kalibeng bawah usia 2.600.000 Tahun

13. RULE Usia Fosil 3.000.000 Tahun IF Tanah lokasi penemuan berupa lempung Is Yes

AND berwarna abu-abu kebiruan Is Yes AND Memiliki ketebalan 107 meter Is Yes AND Merupakan endapan laut dalam Is Yes AND Mengandung lanau Is Yes THEN Lapisan Kalibeng

\subsection{Perancangan dan Program}

Use Case Diagram dari perangkat lunak Paleontologi dapat dilihat pada gambar 2: 


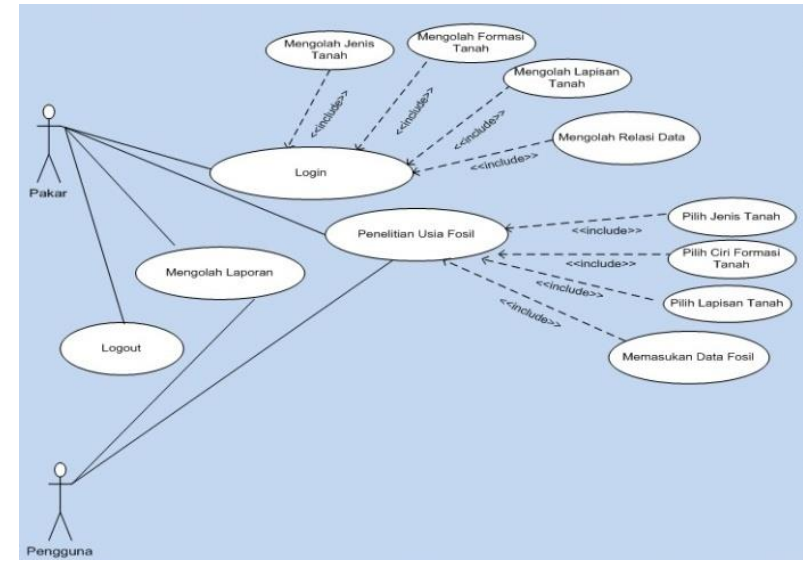

Gambar 2 Use Case Diagaram Perangkat Lunak Paleontologi

Perangkat lunak Paleontologi dibangun dengan bahasa pemrograman Visual Basic 6.0 dan database Microsoft Access. Tampilan Menu pembuka dapat dilihat pada gambar 3

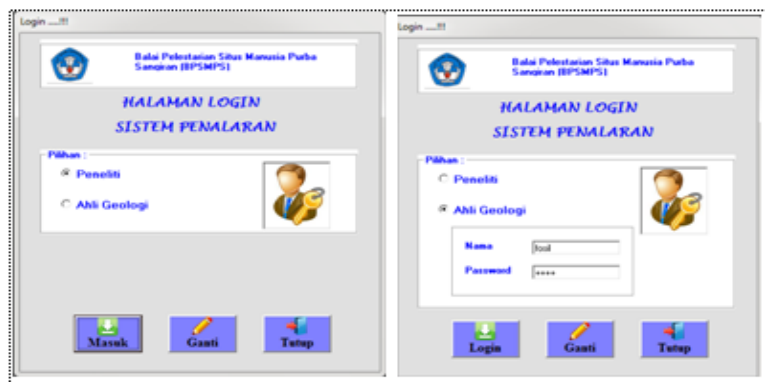

Gambar 3 Halaman Login Pakar dan Non Login untuk Peneliti Fosil

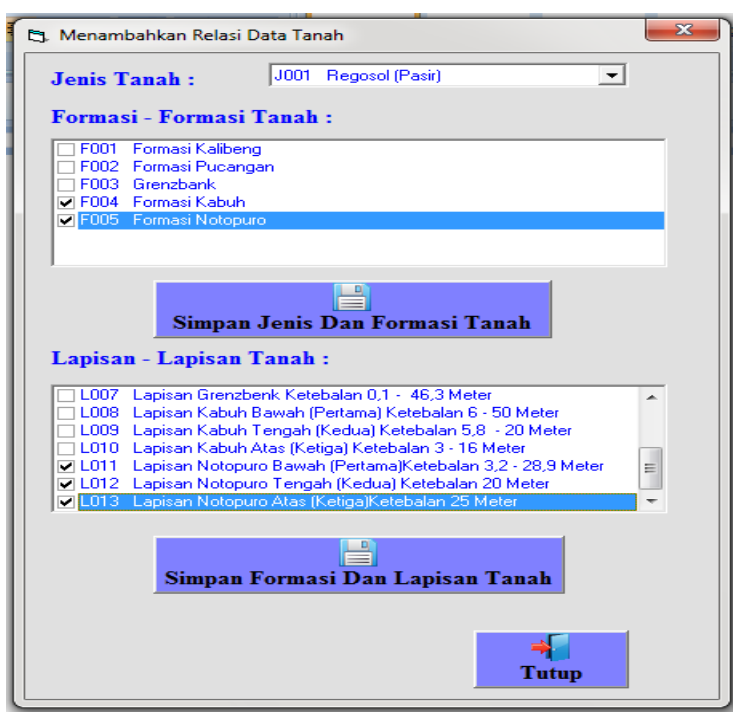

Gambar 4 Menu Relasi Data Tanah

Pada gambar 4 digunakan untuk melihat relasi data antara jenis tanah dengan formasi tanah dan formasi tanah dengan lapisan tanah. Tombol tambah digunakan untuk masuk form tambah relasi data tanah.

Pada form menu penelitian jenis tanah terdapat combobox untuk memilih jenis tanah. Form ini digunakan oleh peneliti fosil untuk menginputkan ciri-ciri lapisan tanah sesuai lokasi penemuan fosil.

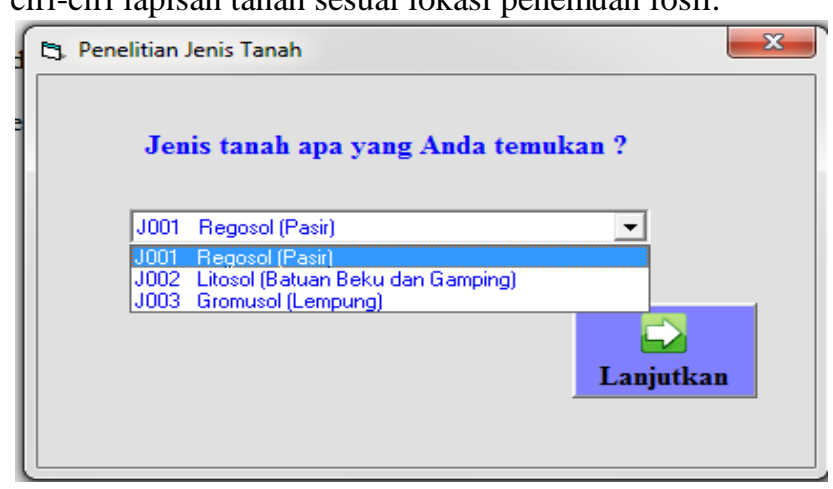

Gambar 5 Menu Penelitian Jenis Tanah

Tombol Lanjutkan gambar 5 digunakan untuk melanjutkan proses penelitian masuk ke form penelitian formasi tanah gambar 6 .

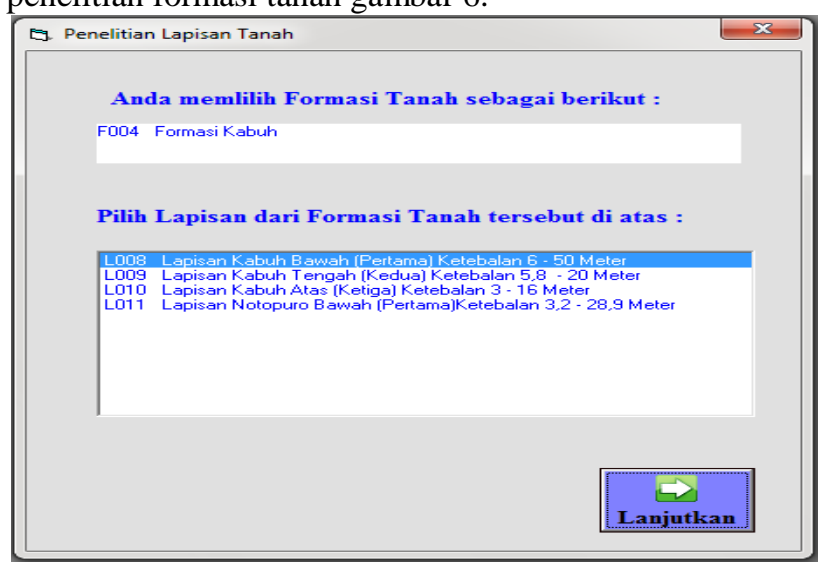

Gambar 6 Menu Lapisan Tanah

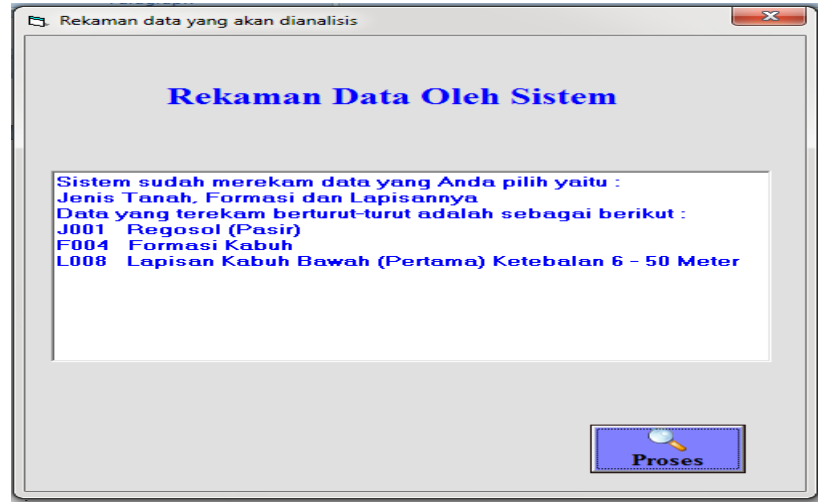

Gambar 7 Halaman Rekam Data

Gambar 7 digunakan untuk menampilkan data jenis, formasi, dan lapisan tanah yang sudah dipilih dalam penelitian. Data tersebut akan dianalisis untuk menghasilkan usia fosil seperti pada gambar 8 . 


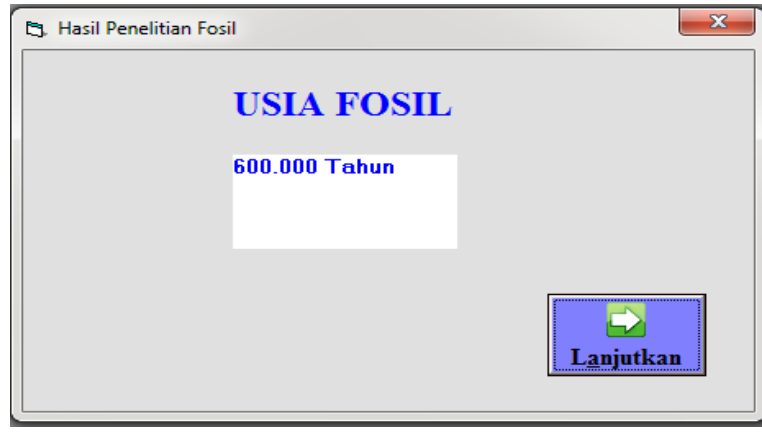

Gambar 8 Halaman Hasil Usia Fosil

Setelah umur fosil dapat teridentifikasi, selanjutnya data penemuan fosil tersebut disimpan pada menu registrasi seperti pada gambar 9 .

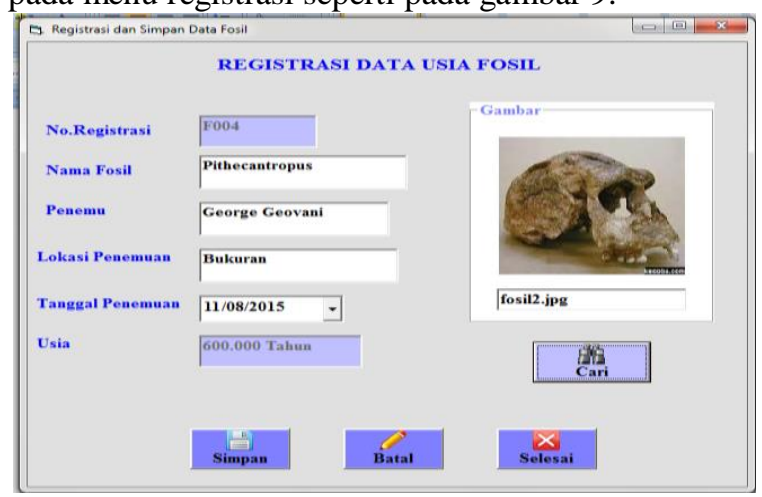

Gambar 9 Halaman Hasil Usia Fosil

\subsection{Pengujian Tingkat Keyakinan Perangkat Lunak}

Metode yang digunakan untuk pengujian adalah Certainly Factor (CF). CF cocok diterapkan pada kasus yang tidak memiliki kepastian penuh. Nilai $\mathrm{CF}$ diberikan oleh pakar besarnya antara -1 sampai dengan 1 (Susanto, 2015). Perangkat lunak paleotologi memiliki kaidah (role) yang serupa, sehingga rumus yang digunakan adalah similary concluded rules (Daniel \& Virginia, 2010). Berikut nilai CF yang didapatkan dari Bpk Muhammad Rais Fathoni, ST selaku pakar dalam penelitian ini. CF pakar dari ciri-ciri usia fosil 11.000 tahun seperti pada tabel 2 berikut:

Tabel 2 Nilai CF Usia Fosil 11.000 tahun

\begin{tabular}{|c|l|c|}
\hline No & \multicolumn{1}{|c|}{ Ciri } & \multicolumn{1}{|c|}{ CF } \\
\hline 1 & Tanah lokasi penemuan berpasir & 0.50 \\
\hline 2 & $\begin{array}{l}\text { Mengandung grave, abu vulkanik, } \\
\text { dan lanau }\end{array}$ & 055 \\
\hline 3 & Merupakan lapisan atas & 0.40 \\
\hline 4 & Memiliki ketebalan 25 meter & 0.70 \\
\hline 5 & Tidak Mengandung pasir besi & 0.35 \\
\hline
\end{tabular}

CF Pada tabel 2 bernilai positif sehingga rumus yang digunakan adalah

$\mathrm{CF}_{\text {COMBINE }}\left(\mathrm{CF}_{1}, \mathrm{CF}_{2}\right)=\mathrm{CF}_{1}+\mathrm{CF}_{2} *\left(1-\mathrm{CF}_{1}\right)$

(Latumakulita, 2012)
Maka nilai CF Tabel 2 untuk usia fosil 11.000 tahun jika dimasukkan pada rumus diatas menjadi:

$\mathrm{CF}_{\mathrm{AB}}\left(\mathrm{CF}_{\mathrm{A}}, \mathrm{CF}_{\mathrm{B}}\right)=0.50+0.55(1-0.50)=0.78$

$\mathrm{CF}_{\mathrm{C}}\left(\mathrm{CF}_{\mathrm{OLD}}, \mathrm{CF}_{\mathrm{C}}\right)=0.78+0.40(1-0.78)=0.87$

$\mathrm{CF}_{\mathrm{D}}\left(\mathrm{CF}_{\mathrm{OLD}}, \mathrm{CF}_{\mathrm{D}}\right)=0.87+0.70(1-0.87)=0.96$

$\mathrm{CF}_{\mathrm{E}}\left(\mathrm{CF}_{\mathrm{OLD}}, \mathrm{CF}_{\mathrm{E}}\right)=0.96+0.70(1-0.96)=0.97$

Sehingga CF usia Fosil 11.000 tahun adalah 0.97 atau $97 \%$ dan usia fosil 120.000tahun seperti dilihat pada tabel 3 .

Tabel 3 Usia Fosil 120.000 tahun

\begin{tabular}{|c|l|c|}
\hline No & \multicolumn{1}{|c|}{ Ciri } & CF \\
\hline 1 & Tanah lokasi penemuan berpasir & 0.50 \\
\hline 2 & $\begin{array}{l}\text { Mengandung grave, abu vulkanik, } \\
\text { dan lanau }\end{array}$ & 0.55 \\
\hline 3 & Merupakan lapisan atas & 0.40 \\
\hline 4 & Memiliki ketebalan 20 meter & 0.75 \\
\hline 5 & Tidak Mengandung pasir besi & 0.35 \\
\hline
\end{tabular}

Maka CF usia fosil 120.000 tahun adalah:

$\mathrm{CF}_{\mathrm{FG}}\left(\mathrm{CF}_{\mathrm{F}}, \mathrm{CF}_{\mathrm{G}}\right)=0.50+0.55(1-0.50)=0.78$

$\mathrm{CF}_{\mathrm{H}}\left(\mathrm{CF}_{\mathrm{OLD}}, \mathrm{CF}_{\mathrm{H}}\right)=0.78+0.40(1-0.78)=0.87$

$\mathrm{CF}_{\mathrm{I}}\left(\mathrm{CF}_{\text {OLD }}, \mathrm{CF}_{\mathrm{I}}\right)=0.87+0.70(1-0.87)=0.97$

$\mathrm{CF}_{\mathrm{J}}\left(\mathrm{CF}_{\mathrm{OLD}}, \mathrm{CF}_{\mathrm{J}}\right)=0.97+0.75(1-0.97)=0.98$

Sehingga CF usia Fosil 120.000 tahun adalah 0.98 atau $98 \%$.

Jika 13 rule dihitung akan menghasilkan CFcombine (CFc) usia Fosil sebesar 0.96 atau $96 \%$.

\section{KESIMPULAN}

Perangkat lunak Paleontology memiliki 13 rule untuk menelusuri usia fosil sesuai dengan proses penentuan usia fosil oleh pakar yang dilakukan pada Balai Besar Situs Manusia Purba Sangiran. Perangkat lunak membantu para ahli geologi untuk menentukan usia fosil secara objektif sesuai dengan kaidah-kaidah penentuan umur fosil dengan metode relatif. Pengujian perangkat lunak dilakukan dengan metode Certainly Factor memiliki tingkat kepercayaan sebesar $96 \%$.

Proses akuisisi dengan metode relatif masih kurang memiliki ketepatan umur yang pasti, sehingga diharapkan peneliti selanjutnya dapat mengembangkan sistem pakar menggunakan basis pengetahuan dengan perhitungan fosil Metode Absolute.

\section{TERIMAKASIH}

Terimakasih kepada Siti Ngaisaroh Endang Sularsih yang telah membantu mencari data penelitian dan kepada Menristek Dikti yang telah memberikan dana hibah penelitian.

\section{SUMBER PUSTAKA/RUJUKAN}

Abraham, A. (2005). Rule-based Expert Systems. (P. Sydenham \& R. Thorn, Eds.)Handbook of 
162 Jurnal Teknologi Informasi dan Ilmu Komputer (JTIIK), Vol. 3, No. 3, September 2016, hlm. 156-162

Measuring System Design (pp. 910-919). John Wiley and Sons, Inc. doi:10.1002/0471497398.mm422

Bacchus, F., \& Ady, M. (2001). Planning with resources and concurrency a forward chaining approach. IJCAI International Joint Conference on Artificial Intelligence, 417-424. Retrieved from www.cs.toronto.edu/ fbacchus/Papers/BAIJC AI01.pdf

Barry, A. (2008). Forward-Chaining Inferencing. US. Retrieved from https://www.google.com/patents/US7418434

Daniel, \& Virginia, G. (2010). Impementasi Sistem Pakar untuk Mendiagnosis Penyakit Dengan Gejala Demam Menggunakan Metode Certainly Factor. Jurnal Informatika, 6(1), 2536.

Fairuz, M. (2005). Expert System for Car Maintenance and Troubleshooting. Generation5. Retrieved March 27, 2015, from http://www.generation5.org/content/2005/Car Maintenance.asp

Fathoni, M. R. (2016). Proses Penentuan umur Metode Relatif di Sangiran. Sangiran: Balai Pelestarian Situs Manusia Purba.

Latumakulita, L. (2012). Sistem Pakar Pendiaknosa Penyakit Anak Menggunakan Certainly Factor (CF). Jurnal Ilmiah Sains, 12(2), 120-126.

Ligeza, A. (2006). Principles of Verification of RuleBased Systems. In Logical Foundations for Rule-Based Systems (p. pp 191-198). Springer Berlin Heidelberg. doi:10.1007/3-540-32446$1 \_12$

Noor, D. (2012). Pengantar Geologi (2nd ed., p. 2). Bogor: Pakuan University Press. Retrieved from http://www.scribd.com/doc/125112208/Penga ntar-Geologi-2012-Djauhari-Noor

Nugraha, S. (2013). Lapisan Tanah dan Lingkungan Purba Sangiran. BPSMPS, 15.

Rendra, S. (2013). Sangiran Situs Fosil Purba yang Diakui Dunia. Sindonews.com. Retrieved June 4, 2016, from http://daerah.sindonews.com/read/759329/22/s angiran-situs-fosil-purba-yang-diakui-dunia$1373428660 / 2$
Subasi, A. (2007). EEG Signal Classification using Wavelet Feature Extraction and a Mixture of Expert Model. Expert Systems with Applications, 32(4), 1084-1093. Retrieved from http://www.sciencedirect.com/science/article/p ii/S0957417406000844

Susanto, C. (2015). Aplikasi Sistem Pakar untuk Menentukan Jenis Gangguan Perkembangan Mental Anak dengan Metode Certainly Factor (Studi Kasus Rumah Sakit Batara Guru Belopa). In Peran Multimedia dalam Industri Kreative dan Optimasi pPenggunaan eGoverment untuk Memperkuat Jati Diri Bangsa (pp. 36-41). Yogyakarta: STMIK AMIKOM Yogyakarta.

Tree, V. B. F. D. of M. C. P. using D. (n.d.). No Title. Expert Systems with Applications, 37(6), 40404049. Retrieved from http://www.sciencedirect.com/science/article/p ii/S0957417409008689

Wahyu, W. P. (2012). Dasar - Dasar Program Perencanaan Dan Perancangan Arsitektur (Dp3a) Sragen Convention Centre. Universitas Muhammadiyah Surakarta. Retrieved from http://eprints.ums.ac.id/21720/ 